\title{
Effect of Endophytic and Plant Growth Promoting Rhizobacteria against Foot Rot Disease of Piper nigrum L.
}

\author{
Shobha M.S. ${ }^{1}$, Mahadeva Murthy S. ${ }^{2 *}$ \\ ${ }^{1}$ Department of Microbiology, Maharani's Science College for Women, Mysuru-570005, India \\ Email:shobamanoj2014@gmail.com \\ 2 Department of Microbiology, Yuvaraja College (Autonomous), University of Mysore, Mysuru- 570005, India \\ Email:smmurthy2025@g mail.com
}

\begin{abstract}
Crop loss in black pepper (Piper nigrum L.) due to pathogenic diseases is mainly induced by soil borne fungi, bacteria, nematodes and viruses. Foot rot disease caused by Phytophthora capsici Leonian is a major production constraint in South India and other south East Asian countries. Combination of biocontrol agents that are compatible with each other is one of the emerging strategies to control plant disease and pest. The present study was designed to evaluate the protective effects of compatible endophytic fungal (Trichoderma harzianum Th16 and Th5) and rhizobacterial (Pseudomonas fluorescens Pf1) strains against pepper foot rot disease. Our results showed that T. harzianum (Th16 and Th5) and P. fluorescens (Pf1) were compatible and effectively inhibited the growth of $P$. capsici. The application of endophytic and rhizobacterial strains, alone and in combination in green house and field conditions were found to be effective in controlling the foot rot of pepper caused by $P$. capsici by inducing systemic resistance (ISR) as evidenced by enhanced activities of PO, PPO, PAL, $\beta$-1,3-glucanase, chitinase and total phenolics involved in the synthesis of phytoalexins thereby promoting the growth of plants. However, combinations of Th16 + Th5 + Pfl were more effective than individual treatments. The findings suggest that synergistic interactions of biocontrol agents may be responsible for the management of foot rot of pepper caused by P. capsici.
\end{abstract}

Keywords-Azadiracta indica, Endophytes, Foot rot of pepper, Phytophthora capsici Leonian, PGPR and PGPE bio-formulations.

\section{INTRODUCTION}

Black pepper (Piper nigrum L.) is a commercial spice crop cultivated in India. India ranks first in the world in terms of production, consumption and exports and the crop is is grown in an area of 131230 ha with an annual production of 55500 tonnes (Indian Spice Board,
India, Feb 2017). Foot rot disease of black pepper caused by Phytophthora capsici is known to affect $90 \%$ of yield in India (Nair and Gupta, 2003; Krishnamoorthy and Parthasarathy 2011). The control of foot rot disease has been almost exclusively based on the application of chemical pesticides that effectively kill the $P$. capsici. Although several effective pesticides have been recommended for use against this pathogen, they are not considered to be long-term solutions due to concerns of expense, exposure risks, fungicide residues, toxicity to non-target organisms and other health and environmental hazards. Therefore, recent efforts have been focused on developing eco-friendly safe, long lasting and effective management strategies against plant pathogens.

Use of biocontrol agents has been shown to be eco-friendly and effective against many plant pathogens and pest. Several biocontrol agents have been documented to prevent foot rot disease by inducing systemic resistance of pepper plants against $P$. capsici. Induced systemic resistance (ISR) activates multiple defense mechanisms that include increased activity of pathogenesis related (PR) proteins like Chitinase, $\beta$-1,3-glucanase and peroxidase (PO) (Maurhofer et al., 1994; Xue et al., 1998), and also the accumulation of low molecular weight substances called phytoalexins (Van Peer and Schippers, 1992). Chitinases and $\beta-1,3$-glucanases are a structurally and functionally diverse group of hydrolytic enzymes involved in defense reactions of plants against pathogens (Jackson and Taylor, 1996), while PO and PAL are the key enzymes involved in phenylpropanoid metabolism (Vidhyasekaran et al., 1997).

Accumulating evidence suggest that the organisms under most scrutiny for potential use in biological control of pest and diseases are bacteria belonging to the genera Pseudomonas and Bacillus (Ramamoorthy et al., 2001). Further, plant growth promoting endophytic bacteria (PGPE), especially Bacillus subtilis (EPCO16 and EPC5) and plant growth 
promoting rhizobacteria (PGPR), especially Pseudomonas fluorescens (Pf1) strains have been developed commercially as a talc based formulation and tested against several crop diseases (Vivekananthan et al., 2004; Rajendran et al., 2007; Kavino et al., 2007 and Harish et al., 2008). Sundaramoorthy et al., 2011 reported that combination of $P$. fluorescens strains and B. subtilis strain together resulted in significant growth promotion that was correlated with induced resistance in Capsicum annum $\mathrm{L}$. Several approaches have been made to manage the foot rot of pepper. However, no attempts have been made for the management of $P$. capsici disease using the mixtures of both PGPR and endophytes. Therefore, the present study was designed to evaluate protective effect of endophytic fungal strains, T. harzianum (Th16 and Th5) and rhizobacterial strain P. fluorescens (Pf1) against foot rot disease.

\section{MATERIAL AND METHODS}

\subsection{Plant materials and pathogen}

The black pepper samples were obtained from Pepper Research Center, Appangala, Mercara, Karnataka. The pathogen was isolated from the black pepper foot showing typical symptoms of $P$. capsici by using Oat meal agar (OMA) medium and the fungal culture was identified based on morphological, conidial and culture characterization using standard fungal manual was send to Department of Studies in Biotechnology, University of Mysore, Mysuru- India for identification purpose and it was identified as $P$. capsici.

\subsection{Biocontrol agents}

The two endophytic fungal strains of $T$. harzianum namely Th16 and Th15 were isolated from bark of Azadiracta indica. In addition, antagonistic strains of $P$. fluorescens Pf1 were collected from Department of Studies in Biotechnology, University of Mysore, Mysuru . Pure strains of endophytic T. harzianum strains (Th16 and Th15) were maintained on potato dextrose agar (PDA) slants and $P$. fluorescens strain (Pf1) was maintained on King's B (KB) agar slants at $4{ }^{\circ} \mathrm{C}$.

\subsection{Efficacy of individual and mixtures of biocontrol} agents on radial growth of $P$. capscici

Pseudomonas fluorescens strain (Pf1) and $T$. harzianum (Th16 and ThC5) strains were tested individually and in combination against $P$. capsici by dual culture technique (Dennis and Webster, 1971). The mycelial disc $(9 \mathrm{~mm})$ from 7 days old culture of $P$. capsici was placed in one side of the Petri plate containing $15 \mathrm{ml}$ of PDA medium. After three days of pathogen inoculation, $72 \mathrm{~h}$ of old bacterial strains $P$. fluorescens and $T$. harzianum strains were streaked on the opposite of the petri plate by the help of sterilized inoculation needle individually on each plate. Three replications were maintained for each treatment. The plates were incubated at room temperature $\left(28 \pm 2{ }^{\circ} \mathrm{C}\right)$ for three days and inhibition zone was measured. The radial growth of the pathogen and per cent reduction over control was calculated by using the following formula

$$
\text { Per cent reduction over control }=\frac{\mathrm{C}-\mathrm{T}}{\mathrm{C}} \times 100
$$

Where, C - Mycelial growth of the pathogen in control $(\mathrm{mm})$ and $\mathrm{T}-$ Mycelial growth of the pathogen in dual plate (mm).

\subsection{Preparation of individual and mixtures of PGPR and PGPE bio-formulations}

For individual strains of $P$. fluorescens (Pf1) and T. harzianum (Th16 and Th5) were inoculated into the sterilized KB and Potato dextrose broth, respectively and incubated in a rotary shaker at $150 \mathrm{rpm}$ for $48 \mathrm{~h}$ at room temperature $\left(28 \pm 2{ }^{\circ} \mathrm{C}\right)$. After $48 \mathrm{~h}$ and 7 days of incubation, the broth containing $9 \times 10^{8} \mathrm{cfu} / \mathrm{ml}$ was used for the preparation of talc-based formulation for bacterial culture. To the $400 \mathrm{ml}$ of bacterial suspension, $1 \mathrm{~kg}$ of the talc powder (sterilized at $105{ }^{\circ} \mathrm{C}$ for $12 \mathrm{~h}$ ), calcium carbonate $15 \mathrm{~g}$ (to adjust the $\mathrm{pH}$ to neutral) and Carboxymethyl cellulose (CMC) $10 \mathrm{~g}$ (adhesive) were mixed under sterile conditions, following the method described by (Nandakumar et al., 2001). After shade drying overnight, it was packed in polypropylene bag and sealed.

\subsection{Greenhouse studies}

2.6.1. Effects of bio-formulation mixtures on the incidence of foot rot disease

To study the induced systemic resistance (ISR) against $P$. capsici of pepper veins, a pot culture experiment was conducted with single and combination of rhizosphere bacteria and endophytic fungus. Veins are grown in earthen pots (Size-0.35 m diameter, $0.50 \mathrm{~m}$ height, volume of soil: $0.04 \mathrm{~m}^{3}$ ) filled with sterilized potting soil containing the spore suspension $\left(2 \times 10^{5}\right.$ spores/g of soil) of $P$. capsici.

In all treatments, the talc-based bio-formulation mixture was applied as seedling root dip and soil application. The fungicide RIDOMIL GOLD ${ }^{\circledR} \mathbf{M Z}$ was used as a positive control. For treatment, the pepper vine cv. Subhakara, hence the cultivar is susceptible to foot rot disease the same cultivar was used for further studies. After 25 days, the seedlings were pulled out from the pots and transplanted at the rate of five vine per pot (Size-0.35 $\mathrm{m}$ diameter, $0.50 \mathrm{~m}$ height, volume of soil: $0.04 \mathrm{~m}^{3}$ ) containing sterilized soil mixture (cow dung: sand: soil in 1:1:1 ratio) inoculated with the spore suspension $\left(2 \times 10^{5}\right.$ spores/g of soil mixture) of $P$. capsici (Sundaramoorthy et al., 2012). For root dipping, pepper veins were dipped in $250 \mathrm{ml}$ of Trichoderma suspension $\left(9 \times 10^{8} \mathrm{cfu} / \mathrm{ml}\right)$ for $2 \mathrm{~h}$, ensuring that roots alone were immersed in the 
inoculum and planted in pots. In soil application, $25 \mathrm{ml}$ of Trichoderma suspension $\left(9 \times 10^{8} \mathrm{cfu} / \mathrm{ml}\right)$ per pot was poured 30 and 60 days after planting $(40-45 \mathrm{~cm}$ height). Vine treated with RIDOMIL GOLD ${ }^{\circledR} \mathbf{M Z}(2 \mathrm{~g} /$ litre $)$ as well as soil drench $(0.1 \%)$ at 30 and 60 days after planting served as a positive control.

The pepper vine inoculated with the pathogen alone served as inoculated control. The observation on development of $P$. capsici symptoms was recorded at the time of harvest. Each treatment was replicated thrice in Completely Randomized Block Design (CRD). The percent disease index (PDI) was estimated using the formula suggested by Mckinney (1923).

Induction of defense-related protein and experimental design

Pseudomonas fluorescens and endophytic ( $T$. harzianum) fungal strains in single and in combinations (Treatments T1-Th16, T2-Th15, T3-Pf1, T4-Th16 + Th15, T5-Th15 + Pf1, T6-Pf1 + Th16, T7-Th16 + Th5 + Pf1, T8-Ridomil gold, T9-inoculated control, T10-healthy control) were used in the induction of defense reactions in pepper. The bio-formulations treated vine were sown at the rate of one veins per pot (Size-0.35 m diameter, 0.50 $\mathrm{m}$ height, volume of soil: $0.04 \mathrm{~m}^{3}$ ) filled with sterilized potting soil containing the spore suspension $\left(2 \times 10^{5}\right.$ spores/g of soil) of $P$. capsici. Bio-formulation treated plants were challenge inoculated with $P$. capsici, while the other set were not challenge inoculated. The plants neither treated with bio-formulation nor challenged by the pathogen were kept as a control. Three replications were maintained in each treatment. Each replicate consisted of five pots and in each pot one vine were maintained. The experiments were conducted using CRD in greenhouse. The humidity in the greenhouse was maintained at around RH $70 \%$. The temperature was adjusted to $26^{\circ} \mathrm{C}$ (day)/20 ${ }^{\circ} \mathrm{C}$ (night).

\subsubsection{Sample collection and assay of defense-related} proteins

Vine leaf tissues were collected at different time intervals $(0,4,8,16,24,48$ and 72 hours after pathogen inoculation). Four pepper vines were sampled from each replication of the treatment separately and were maintained for biochemical analysis. Leaf samples were homogenized with liquid nitrogen in a pre-chilled mortar and pestle. One gram of leaf sample was homogenized with $2 \mathrm{ml}$ of $0.1 \mathrm{M}$ sodium phosphate buffer ( $\mathrm{pH} 7.0)$ at 4 ${ }^{\circ} \mathrm{C}$. The homogenate was centrifuged for $20 \mathrm{~min}$ at 10,000 $\mathrm{rpm}$. The supernatant was used as a crude enzyme extract for assaying PO (Hammerschmidt et al., 1982), polyphenol oxidase (PPO) (Mayer et al. 1965) and PAL (Dickerson et al., 1984). Enzyme extracted in $0.1 \mathrm{M}$ sodium citrate buffer ( $\mathrm{pH}$ 5.0) was used for the estimation of chitinase (Boller and Mauch 1988) and $\beta$-1,3-glucanase
(Pan et al., 1991). The total phenol content was estimated as per the procedure given by (Zieslin and Ben-Zaken 1993).

2.6.4. Native polyacrylamide gel electrophoresis analysis

The isoform profiles of $\mathrm{PO}$ and PPO were studied by discontinuous Native polyacrylamide gel electrophoresis analysis (PAGE) (Laemmli 1970). The protein extract was prepared by homogenizing $1 \mathrm{~g}$ of leaf sample in $2 \mathrm{ml}$ of $0.1 \mathrm{M}$ sodium phosphate buffer $(\mathrm{pH}$ 7.0) and centrifuged at $18,000 \mathrm{rpm}$ for $20 \mathrm{~min}$ at $4{ }^{\circ} \mathrm{C}$. The protein content of the sample was determined (Bradford 1976) and samples (50 $\mu$ g protein) were loaded into $8 \%$ polyacrylamide gels (Sigma, USA). After electrophoresis, $\mathrm{PO}$ isoforms were visualized by soaking the gels in staining solution containing $0.05 \%$ benzidine (Sigma-Aldrich, Mumbai, India) and $0.03 \% \mathrm{H}_{2} \mathrm{O}_{2}$ in acetate buffer $(20 \mathrm{mM}, \mathrm{pH} 4.2)$ (Nadolny and Sequeira 1980). For assessing the PPO isoform profiles, the gels were equilibrated for $30 \mathrm{~min}$ in $0.1 \% p$-phenylene diamine, followed by the addition of $10 \mathrm{mM}$ catechol in the same buffer (Jayaraman et al., 1987).

\subsection{Statistical analysis}

The data on effect of the treatments on the growth of pathogens, severity of diseases and activity of enzymes in pepper vine were analyzed by analysis of variance (ANOVA), and treatment means were compared by Duncan's Multiple Range Test (DMRT). The data on disease severity was arcsine transformed before undergoing statistical analysis (Gomez and Gomez 1984).

\section{RESULTS}

\subsection{Compatibility among bacterial strains}

PGPR strain of P. fluorescens (Pf1) and PGPE strains of T. harzianum (Th16 and Th15) were tested for their compatibility in vitro. None of the antagonistic bacteria were inhibited by each other, So the absence of inhibition zone suggesting that these three biocontrol agents were compatible with each other.

\subsection{Effect of biocontrol agents on radial growth of $P$. capsici}

One strain of P. fluorescens (Pf1) and two strains of $T$. harzianum (Th16 and Th15) were tested individually and in combination to assess the effect of biocontrol agents on radial growth of $P$. capsici. All the treatments were effective in reducing the mycelial growth of the pathogen. However, the combined application of Th16+ Th15 + Pf1, Th16 + Th15 and Th16 + Pf1 had resulted in the least mycelial growth with 49.0, 54.0 and $54.1 \mathrm{~mm}$, respectively. Combined application of Th $16+$ Th $15+$ Pf 1 and Th16+ Th15 and Th16+ Pf1 recorded the maximum inhibition zone of 26.0, 23.5 and $19.5 \mathrm{~mm}$, respectively. The control plates recorded the highest mycelial growth of $90.00 \mathrm{~mm}$ (Table 1). 
Table.1: Effect of biocontrol agents on the mycelial growth of P. capsici

\begin{tabular}{|l|l|l|l|l|}
\hline $\begin{array}{l}\text { Sl. } \\
\text { No }\end{array}$ & Treatments & $\begin{array}{l}\text { Mycelial } \\
\text { growth }(\mathbf{m m})\end{array}$ & $\begin{array}{l}\text { Inhibition zone } \\
(\mathbf{m m})\end{array}$ & $\begin{array}{l}\text { Percent inhibition over } \\
\text { control (mm) }\end{array}$ \\
\hline 1 & Th16 & $61.00^{\mathrm{de}}$ & $10.00^{\mathrm{f}}$ & $32.22^{\mathrm{de}}$ \\
\hline 2 & Th5 & $63.50^{\mathrm{ef}}$ & $8.70^{\mathrm{g}}$ & $29.44^{\mathrm{ef}}$ \\
\hline 3 & Pf1 & $70.40^{\mathrm{g}}$ & $7.00^{\mathrm{h}}$ & $21.77^{\mathrm{g}}$ \\
\hline 4 & Th16+ Th5 & $54.00^{\mathrm{b}}$ & $23.50^{\mathrm{b}}$ & $40.00^{\mathrm{b}}$ \\
\hline 5 & Th5+ Th5 & $56.20^{\mathrm{bc}}$ & $15.20^{\mathrm{d}}$ & $37.55^{\mathrm{bc}}$ \\
\hline 6 & Pf1 + Th16 & $54.10^{\mathrm{b}}$ & $19.50^{\mathrm{c}}$ & $39.89^{\mathrm{b}}$ \\
\hline 7 & Th16+ Th5 + Pf1 & $49.00^{\mathrm{a}}$ & $26.00^{\mathrm{a}}$ & $45.55^{\mathrm{a}}$ \\
\hline 8 & RIDOMIL GOLD & $58.00 \mathrm{~b}^{\mathrm{cd}}$ & $13.10^{\mathrm{e}}$ & $35.55^{\mathrm{cd}}$ \\
\hline 9 & Control & $90.00^{\mathrm{h}}$ & 0.00 & 0.00 \\
\hline
\end{tabular}

Values are mean of three replications. In a column, mean followed by a common letter (s) are not significantly differe nt at the $5 \%$ level by DMRT.

3.3. Efficacy of PGPR and PGPE strains on foot rot incidence under greenhouse conditions

Talc-based bio-formulation of $P$. fluorescens (Pf1) and T. harzianum (Th16 and Th15) strains individually or in combination were tested for their efficacy against $P$. capsici under pot culture conditions, along with RIDOMIL GOLD as a chemical check. Both individual and strain mixtures significantly reduced the foot rot incidence (by 21-35\%) compared to untreated plants upon challenge inoculation of P. capsici (Fig. 1). Conspicuously, a combination of Th16+Th15+ Pf1 together resulted in a significantly lower foot rot disease index (PDI) than any of the strains individually, as well as better germination $(96 \%)$ and plant height $(73.62 \mathrm{~cm})$ (Fig. 2). The results indicated that disease reduction by a combination of antagonistic bacterial and endophytic strains was comparable with the fungicide control, which recorded the PDI of $22 \%$ and $18 \%$, respectively.

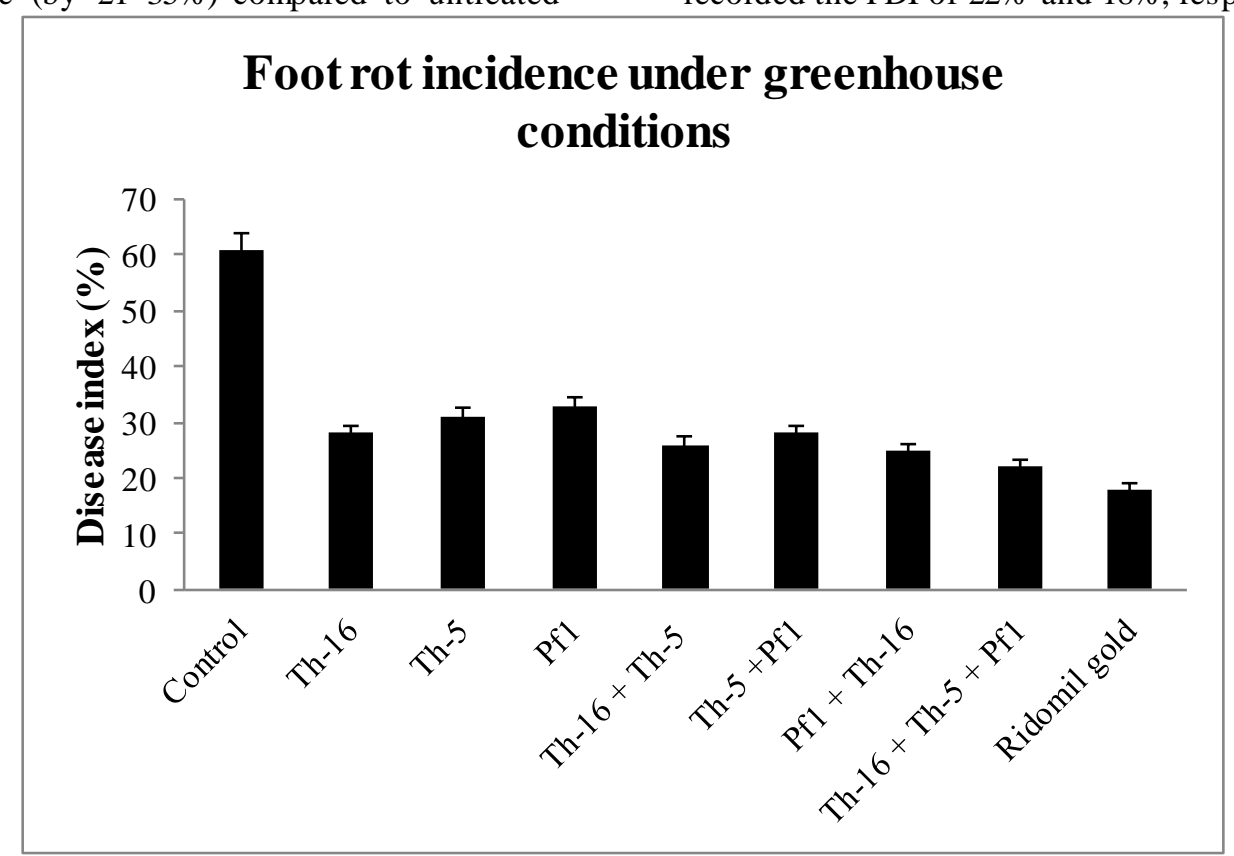

Fig.1: Efficacy of individual and mixture of biocontrol agents on foot rot incidence in black pepper under greenhouse conditions. Values are mean of three replications. The line on each bar represents $\pm S E$ and the values in the bars are not significantly different at the 5\% level according to DMRT. 


\section{Germination (\%) and Plant Height (cm)}

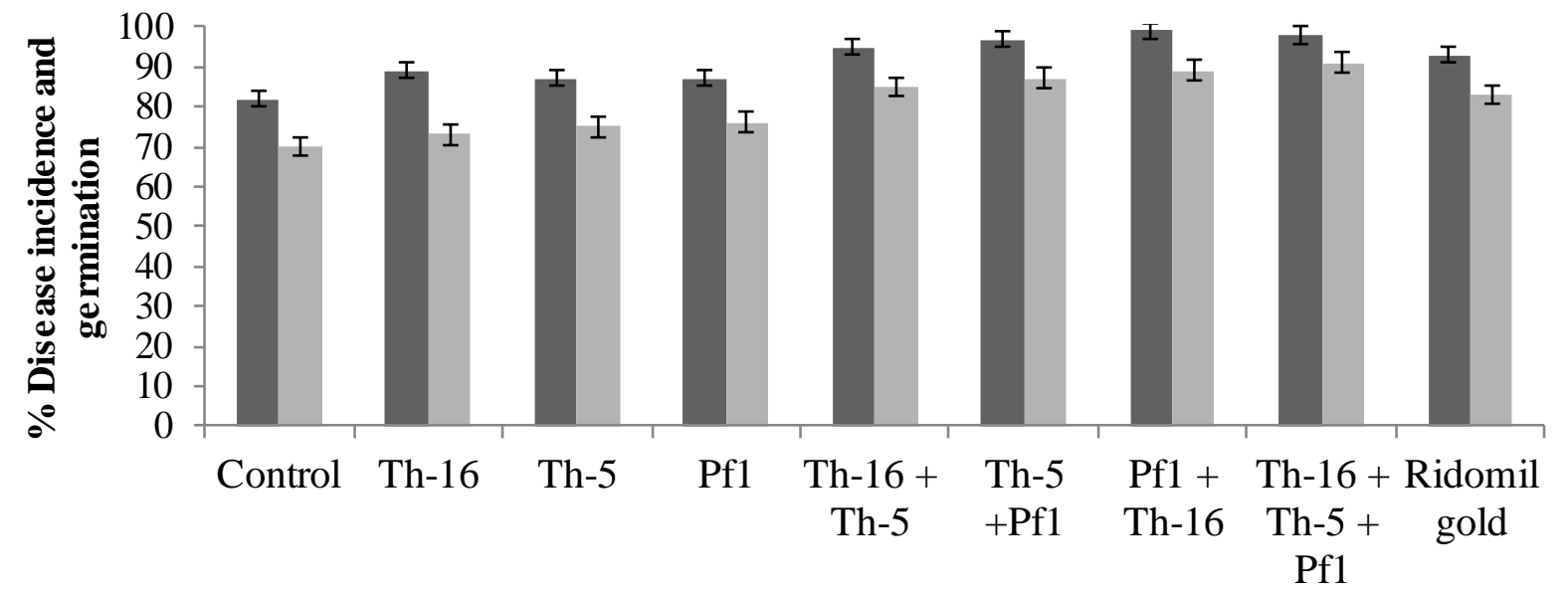

Fig.2: Effect of individual and mixture of biocontrol agents on growth promoting activity in black pepper under greenhouse condition. Values are mean of three replications. The line on each bar represents $\pm S E$ and the values in the bars followed by the common letter(s) are not significantly different at the 5\% level according to DMRT.

3.4. Activity of defense enzymes and pathogenesisrelated (PR) proteins

Induction of defense enzymes and pathogenesis related $(\mathrm{PR})$ proteins was studied in the rhizobacteria and endophytes treated pepper veins. The results revealed higher expression of defense-related proteins upon challenge inoculation with P. capsici. P. fluorescens and T. harzianum strains individually and in a mixture differ in the ability to stimulate PO and PPO in pepper veins challenge inoculated with $P$. capsici. The results of the study revealed that there was an increase PO and PPO activities in Th16 + Th15 + Pf1 mixtures treated plants compared to untreated control plants upon challenge inoculation. The activities (Th16+Th15 + Pf1) were found to increase 110 units of protein at 48 hours after inoculation, compared to all other treatments with drastic reduction in enzyme activities in later time points. The pathogen inoculation in untreated control plants also stimulated the enzymes but the level was less than that of mixture of $P$. fluorescens and T. harzianum pretreated plants (Fig. 3 and Fig. 4).

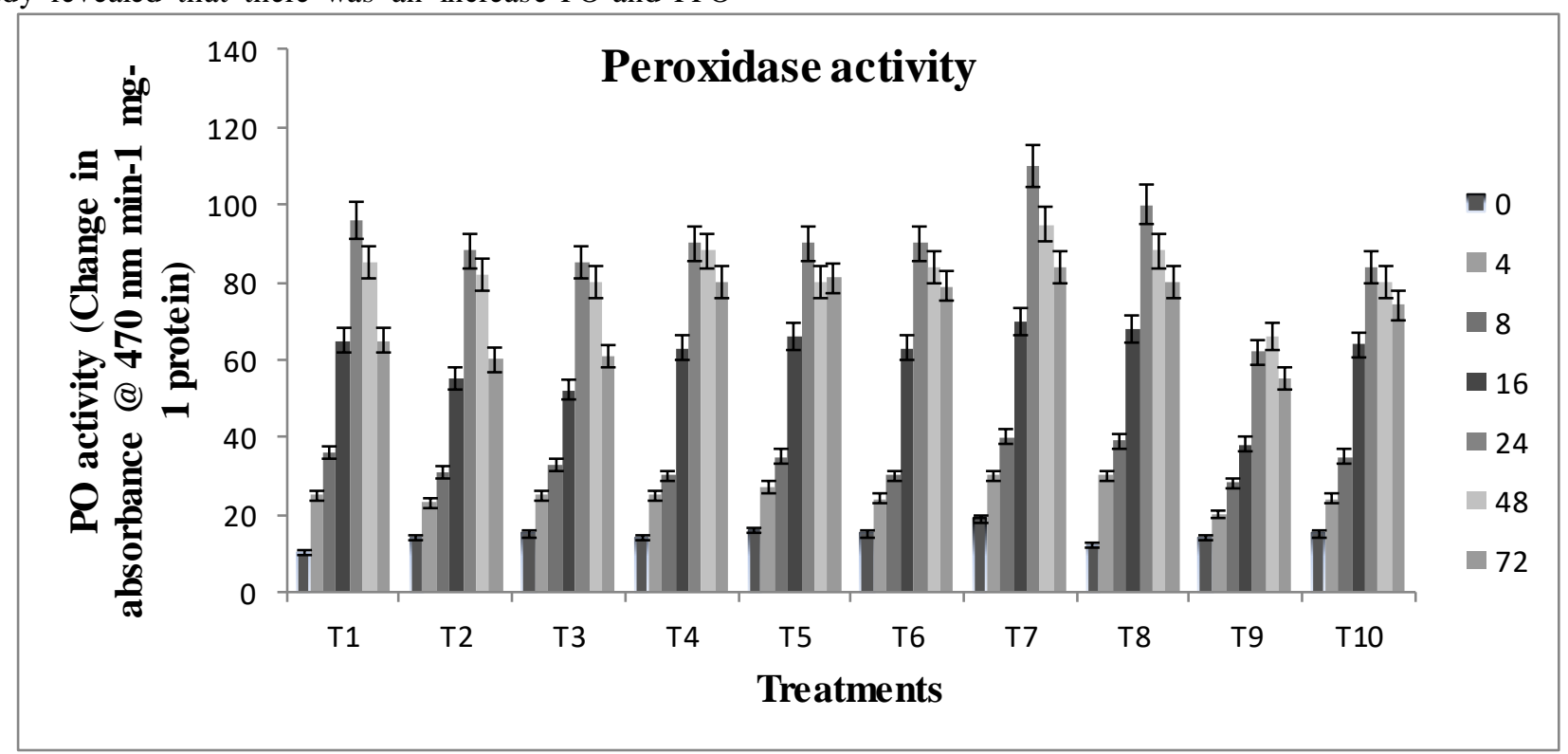

Fig.3: Induction of peroxidase activity in pepper veins treated with biocontrol agents against P. capsici. The vertical bar indicate the SE at 5\% level according to DMRT. Treatments T1-Th16, T2-Th15, T3-Pf1, T4-Th16 + Th15, T5-Th15 + Pf1, T6-Pf1 + Th16, T7-Th16 + Th5 + Pf1, T8-Ridomil gold, T9-inoculated control, T10-healthy control 


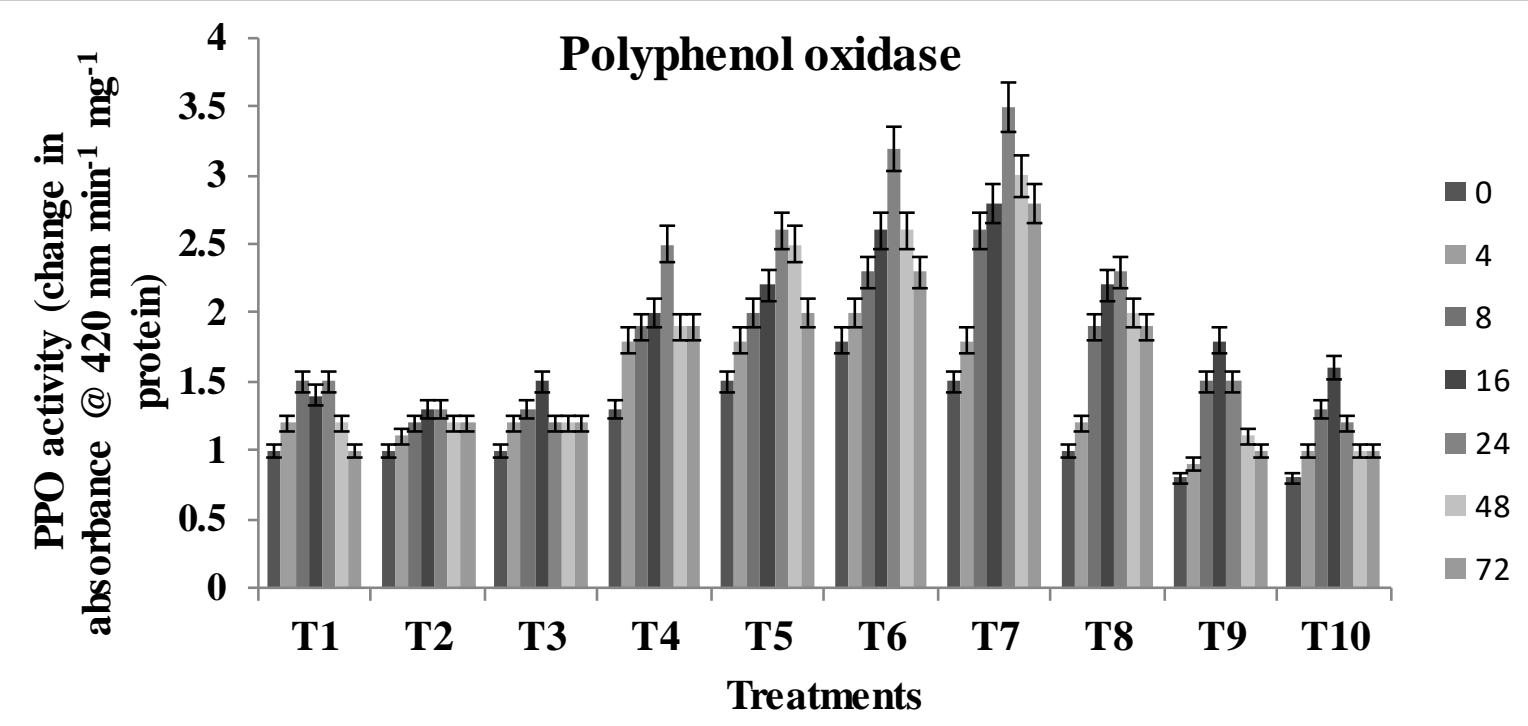

Fig.4:

Induction of polyphenol oxidase activity in pepper veins treated with biocontrol agents against $P$. capsici. The vertical bar indicate the SE at 5\% level according to DMRT. Treatments T1-Th16, T2-Th15, T3-Pf1, T4-Th16 + Th15, T5-Th15 + Pf1, T6-Pfl + Th16, T7-Th16 + Th15 + Pf1, T8-Ridomil gold, T9-inoculated control, T10-healthy control

PAL activity was significantly higher in Th16 + Th15 + Pf1 mixture treated pepper veins inoculated with $P$. capsici than in untreated controls. PAL accumulation reached a maximum of 3.5 units of protein at 24 hours after inoculation in Th16+ Th15 + Pf1 treatment group when compared to all other treatment groups. Untreated pepper veins inoculated with $P$. capsici recorded the least induction of 1.4 units of protein and showed drastic decline at 48 hours after inoculation (Fig. 5).



Fig.5: Induction of phenylalanine ammonia-lyase activity in pepper veins treated with biocontrol agents against P. capsici, the vertical bar indicate the SE at 5\% level according to DMRT. Treatments T1-Th16, T2-Th15, T3-Pf1, T4-Th16 + Th15,

T5-Th15 + Pf1, T6-Pf1 + Th16,T7-Th16 + Th15 + Pf1, T8-Ridomil gold, T9-inoculated control, T10-healthy control 




Fig.6: Induction of $\beta-1,3-$ glucanase activity in pepper veins treated with biocontrol agents and endophytes against $P$. capsici, the vertical bar indicate the SE at 5\% level according to DMRT. Treatments T1-Th16, T2-Th15, T3-Pf1, T4-Th16 + Th15, T5-Th15 + Pf1, T6-Pf1 + Th16, T7-Th16 + Th5 + Pf1, T8-Ridomil gold, T9-inoculated control, T10-healthy control $\beta$ -

1,3-glucanase $($ Th16 + Th15 + Pf1) mixture treated plants inoculated with $P$. capsici. Showed an enhanced activity of 1.7 units of protein at 16 hours after inoculation when compared to untreated control plants which showed 0.8 units of protein. The activities of $\beta$-1,3-glucanase increased in plants treated with bio-formulation mixture $($ Th16 + Th15 + Pf1) up to 3 days after $P$. capsic $i$ inoculation, and declined thereafter as shown in (Fig. 6). Maximum accumulation of total phenol content was also observed in the combination treatments ofTh16+ Th5 + Pf1 followed by Th16 + Th15 and Th16 + Pf1 (Fig. 7). Untreated control, or inoculated with the pathogen alone did not show any remarkable change in the activity of phenolic substances. These results clearly indicate that the defense enzymes and PR proteins were more activated in the mixtures of bacterial bio-formulations treated plants thus strengthening the pepper veins against the abiotic stress.

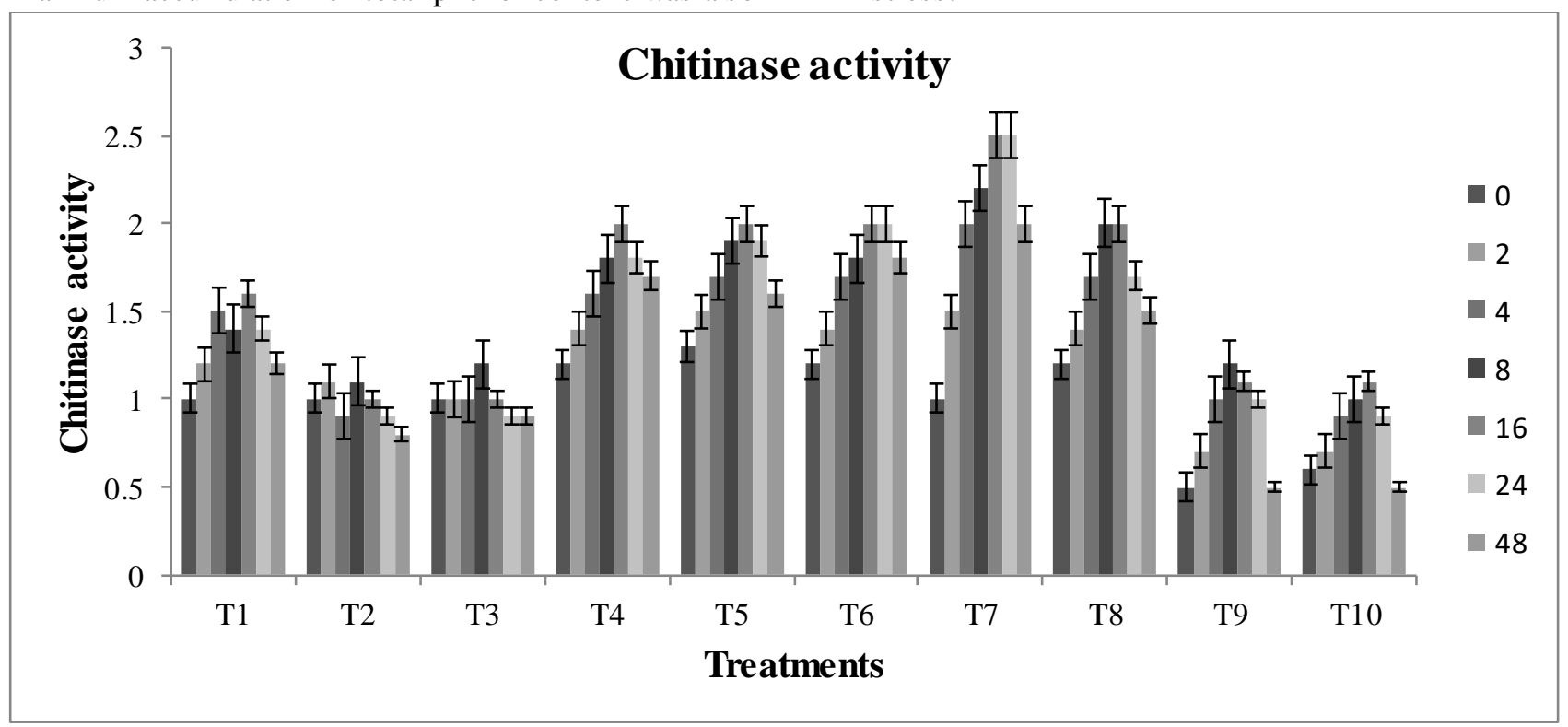

Fig..7: Induction of chitinase activity in pepper veins treated with biocontrol agents and endophytes against $P$. capsici, the vertical bar indicate the SE at 5\% level according to DMRT. Treatments T1-Th16, T2-Th15, T3-Pf1, T4-Th16 + Th15, T5-

Th15 + Pf1, T6-Pf1 + Th16, T7-Th16 + Th5 + Pf1, T8-Ridomil gold, T9-inoculated control, T10-healthy control

The chitinase activity was found high in Th16+ Th5 + Pf1 and Ridomil treated (T8) veins showed 2.5 and 2.0 at $16 \mathrm{hpi}$ and $24 \mathrm{hpi}$. The activities of chitinase activity increased in plants treated with bio-formulation mixture (Th16 + Th15 + Pf1) up to 3 days after P. capsici inoculation, and declined thereafter as shown in (Fig. 7). 
Untreated control, or inoculated with the pathogen alone did not show any remarkable change in the activity as shown in the figure.

\section{DISCUSSION}

Accumulating evidence from literature has shown that compatible multiple strains appear to be an important pre-requisite for the desired effectiveness of strains and more consistent disease suppression (Young Cheol et al., 2008; Latha et al., 2009). The results of the present study provide evidence that the compatibility of P. fluorescens (Pf1) and T. harzianum (Th16 and Th15) effectively inhibited the growth of $P$. capsici. Several studies have documented that Pseudomonas, B. subtilis (CA32) and Trichoderma harzianum (RU01) significantly reduced the mycelial growth and conidial production of $P$. capsici (Abeysingne 2007) by producing the wide array of antibiotics such as 2,4-diacetylphloroglucionl, oligomycin, phenazine, pyoleteorin, pyrolnitrin, pyocyanin, lturin, bacillomycin, zwittermycin-A and surfactin responsible for antifungal activities (Yu et al., 2002).

Inhibitory effect of biocontrol agents observed in dual culture technique is correlated with the management of wilt disease of foot rot caused by $P$. capsici under green house as well as field conditions. The results of the present study revealed that the talc based bio-formulations prepared by using individual and in combination of Th16 + Th15 + Pf1 strains significantly reduced the wilt disease incidence in pepper. This effect may be due to its stimulatory effects on ISR as evidenced by increased activities of defense enzymes such as PO, PPO and PAL involved in the synthesis of phytoalexins thereby induce systemic resistance against foot rot disease and promote the growth of plants. Our results substantiate the inhibition of various plant pathogen and disease management by using several biocontrol agents through the induction of ISR in plants reported by (Van Peer et al., 1991; Kloepper, 1993; Van Loon, 1997; Chen et al., 2000). Thus, our findings provide evidence that the induction of defense enzymes and PR proteins by application of endophytic fungi and rhizosphere bacterial strains may strengthen the plants against various biotic stresses.

\section{CONCLUSION}

The present study demonstrated that the combinations of endophytic fungi Th16 + Th15 + Pf1 bacterial strains consistently reduced the radial mycelial growth of $P$. capsici by producing various antibiotics and reduced the foot rot of pepper under green house and field conditions by inducing ISR compared to individual agents. Combination of biocontrol agents is a strategic approach to control the plant disease and pest (Nandakumar et al., 2001a and Saravanakumar et al.,
2007). Furthermore, interactions among the bacterial strains may have synergis tic effects that could induce ISR and promote the growth of the plants (Sundaramoorthy et al., 2007). Several literature have documented that the use of biocontrol agents in combination was more effective for management of plant diseases and pathogens compared to individual agents (Sivakumar, 2012).

\section{REFERENCES}

[1] Abeysingne, (2007). Biological control of Fusarium solani $\mathrm{f}$. sp. phaseoli the causal agent of root rot of bean using Bacillus subtilis CA32 and Trichoderma harzianum RU01. Ruhuna Journal of Science, 2, 8288.

[2] Boller T. and Mauch, F. (1988). Colorimetric assay for chitinase. Methods in Enzymology, 161, 430435.

[3] Chen, C., Belanger, R.R. Benhamou, N. and Paullitz, T.C. (2000). Defense enzymes induced in cucumber roots by treatment with plant-growth promoting rhizobacteria (PGPR). Physiological and Molecular Plant Pathology, 56: 13-23.

[4] Dickerson, D.P. Pascholati, A.E., Hagerman, L.G. Butler and R.L. Nicholson, S.F. (1984). Phenylalanine ammonia-lyase and hydroxy cinnamate CoA ligase in maize mesocotyls inoculated with Helminthosporium maydis or Helminthosporium carbonum. Physiology and Plant Pathology, 25, 111-123.

[5] Gomez K.A. and Gomez A.A. (1984). Statistical Procedure for Agricultural Research, John Wiley and Sons, New York

[6] Hammerschmidt, R. Nuckles and J. Kuc, E.M. (1982). Association of enhanced peroxidase activity with induced systemic resistance of cucumber to Colletotrichum lagenarium. Physiological Plant Pathology, 20, 73-82.

[7] Harish, S. M. Kavino, N. Kumar, D. Saravanakumar, K. Soorianasundaram and Samiyappan, R. (2008). Biohardening with plant growth promoting rhizosphere and endophytic bacteria induces systemic resistance against banana bunchy to virus. Applied Soil Ecology, 39, 187-200.

[8] Indian Spice Board, India, Feb 2017

[9] Jackson A.O. and Taylor, C.B. (1996). Plantmicrobe interactions: life and death at the interface. Plant Cell, 8, 1651-1680.

[10] Jayaraman, K.S. Ramanuja, M.N. Vijayaraghavan P.K. and Vaidyanathan, C.S. (1987). Oxidative enzyme in pearl millet. Food Chemistry, Wiley and Sons, New York, 24, 203.

[11] Kavino, M. S. Harish, N. Kumar, D. Saravanakumar, T. Domodaran, K. Soorianasundaram and Samiyappan, R. (2007). Rhizosphere and endophytic 
bacteria for induction of systemic resistance of banana plantlets against bunchy top virus. Soil Biology \& Biochemistry, 39, 1087-1098

[12] Kloepper, J.W. (1993). Plant growth-promoting rhizobacteria as biological control agents, B. Metting, Editor, Soil Microbial Technologies, Meeting B, M. Dekker Inc, New York, pp. 255-274.

[13] Krishnamoorthy, B., and Parthasarathy, V. A. (2011). Improvement of black pepper. Plant Sciences Reviews 2010, 37.

[14] Laemmli, U.K. (1970). Cleavage of structural proteins during the assembly of the head of bacteriophage T4. Nature, 227, 680-685.

[15] Latha, P., Anand, T. N. Ragupathi, V. Prakasam and R. Samiyappan, (2009). Antimicrobial activity of plant extracts and induction of systemic resistance in tomato plants by mixtures of PGPR strains and zimmu leaf extract against Alternaria solani. Biological Control, 50, pp. 85-93.

[16] Maurhofer, M. C. Hase, D. Maurwly, J.P. Metraux and Defago, G. (1994). Induction of systemic resistance of tobacco to tobacco necrosis virus by the root colonizing Pseudomonas fluorescens strain CHA0: influence of the gac A gene and of pyoverdine production. Phytopathology, 84, 136146.

[17] Mayer, E. Harel and R.B. Shaul, A.M. (1965). Assay of catechol oxidase a critical comparison of methods. Phytochemistry, 5, 783-789.

[18] Mckinney, H.H. (1923). A new system of grading plant diseases. Journal of Agricultural Research, 26, 195-218

[19] Nadolny, L. and Sequeira, I. (1980). Increases in peroxidase activities are not directly involved in induced resistance in tobacco. Physiology and Plant Pathology, 16, 1-8.

[20] Nair, R.R., and Gupta, S.D. (2003). Somatic embryogenesis and plant regeneration in black pepper (Piper nigrum L.). Direct somatic embryogenesis from tissue of germinating seeds and ontogeny of somatic embryos. J. Hortic. Sci. Biotchnol 78: 416-421.

[21] Nandakumar, R. Babu, S.R., Viswanathan, J., Sheela, T., Raguchander and Samiyappan, A. (2001). New bio-formulation containing plant growth promoting rhizobacterial mixture for the management of sheath blight and enhanced grain yield in rice. BioControl, 46 (4): 493-510.

[22] Nandakumar, R. S. Babu, R. Vis wanathan, J. Sheela, T. Raguchander and R. Samiyappan, A. (2001). A new bio-formulation containing plant growth promoting rhizobacterial mixture for the management of sheath blight and enhanced grain yield in rice. BioControl, 46 4, pp. 493-510
[23] Pan, S.Q., Ye, X.S. and Kuc, J. (1991). Association of $\beta$-1,3-glucanase activity and isoform pattern with systemic resistance to blue mold in tobacco induced by stem injection with Pernospora tabacina or leaf inoculation with tobacco mosaic virus. Physiological and Molecular Plant Pathology, 39, 25-39.

[24] Rajendran, L. G. Karthikeyan, T. Raguchander and Samiyappan, R. (2007). In vitro evaluation of bacterial endophytes influence on Ganoderma lucidum (leys) Karst. mycelial growth.. Journal of Plant Protection Research, 47 (4), 425-436.

[25] Ramamoorthy, V. R., Vis wanathan, T. Raguchander, Prakasam V. (2001). Induction of systemic resistance by plant growth promoting rhizobacteria in crop plants against pest and diseases. Crop Protection, 20, 1-11.

[26] Saravanakumar, C. Vijayakumar, N. Kumar and R. Samiyappan, (2007). PGPR-induced defense responses in the tea plant against blister blight disease. Crop Protection, 26, 556-565.

[27] Sivakumar, G. (2012). Management of Phytophthora foot rot of black pepper with potassium phos phonate (Akomin) and Trichoderma harzianum. Journal of Myclogy and Plant Pathology, 42, 372-375.

[28] Sundaramoorthy, S., Raguchander, T., Ragupathi, N., and Samiyappan, R. (2012). Combinatorial effect of endophytic and plant growth promoting rhizobacteria against wilt disease of Capsicum annum L. caused by Fusarium solani. Biological Control, 60(1), 59-67.

[29] Van Loon L.C. (1997). Induced resistance in plants and the role of pathogenesis-related proteins. European Journal of Plant Pathology, 103, 753765.

[30] Van Peer, R. and Schippers, B. (1992). Lipopolysaccharides of plant growth promoting Pseudomonas spp. strain WCS417r induce resistance in carnation to Fusarium wilt. Netherland. Journal of Plant Pathology, 98, 129-139.

[31] Van Peer, R., Neimann, G.J. and Schippers, B. (1991) Induced resistance and phytoalexin accumulation in biological control of Fusarium wilt of carnation by Pseudomonas sp. strain WCS417r. Phytopathology, 81, 728-734.

[32] Vidhyasekaran, P. Ponmalar, T.R. Samiyappan, R. R. Velazhahan, R. Vimala and A. Ramanathan, A. (1997). Host specific toxin production by Rhizoctonia solani, the rice sheath blight pathogen. Phytopathology, 87, 1258-1263.

[33] Vivekananthan, R. M., Ravi, A. Ramanathan and Samiyappan, R. (2004). Lytic enzymes induced by Pseudomonas fluorescens and other biocontrol organisms mediate defence against the anthracnose 
pathogen in mango. World Journal of Microbiology and Biotechnology, 20, 235-244

[34] Xue, L., Charest, P.M. and Jabaji, S.H. (1998). Systemic induction of peroxidases, $\beta$-1,3-glucanases, chitinases and resistance in bean plants by binucleate Rhizoctonia species. Phytopathology, 88, 359-365.

[35] Young Cheol, K.J. Hyunchae, K. Kil Yong and Seur Kee, P. (2008). An effective biocontrol bioformulation against Phytophthora blight of pepper using growth mixtures of combined chitinolytic bacteria under different field conditions. European Journal of Plant Pathology, 120, 373382

[36] Yu, G.Y., Sinclair, J.B., Hartman, G.L. and Bertagnolli, B.L. (2002). Production of iturin A by Bacillus amyloliquefaciens suppressing Rhizoctoniasolani. Soil Biology \& Biochemistry, 34, 955-963.

[37] Zieslin, N., and Ben-Zaken, R. (1993). Peroxidase activity and presence of phenolic substances in peduncles of rose flowers. Plant Physiology and Biochemistry, 31(3): 333-339. 